\title{
Indonesia's contribution in tracing the human ancestor
}

\section{Fachroel Aziz}

Expert for Geological Museum Bandung, Jalan Diponegoro 57, Bandung 40122, Indonesia

\begin{abstract}
Since Darwin's postulated the origin of the human species from an ape-like ancestor, the search for the missing link between ape and human had begun. In 1887, Eugene Dubois traveled from the Netherlands to Indonesia to search for the missing link. He eventually discovered human fossils in Wajak, Kedungbrubus, and Trinil to which he named Pithecanthropus erectus. The research was then continued by Ter Haar (1931) in Ngandong, Dujfyes, and his assistant Andoyo (1936) in Perning, Mojokerto, and Von Koenigswald (1936-1940) in Sangiran, who successfully discovered many Homo erectus fossils. Since the 1960s, Sartono (ITB), T. Jacob (UGM), and Geological Research and Development Centre (Indonesia) continued the study, adding the collection of the specimens. Collaboration with the National Museum of Science and Nature, Tokyo concluded that Indonesian Homo erectus went through local evolution instead of static evolution condition. Indonesia is rich in natural resources and environmental conditions that were suitable for the evolution of early humans as shown by the discovery of several Homo erectus skeleton fossils that were not found in most other countries. This is a blessing left by early humans to us.
\end{abstract}

Keywords: Homo erectus, Pithecanthropus erectus, human ancestor

Copyright (C2021. FOSI. All rights reserved.

A Special Publication of abstracts and extended abstracts from the conference in honor of the retirement of Prof. Yahdi

Zaim, IPU (22-23 March 2021).

DOI: $10.51835 /$ bsed.2021.47.3.349 


\section{HUMAN ANCESTOR RESEARCH IN INDONESIA}

\section{9 th century}

In the middle 19th century, the history of human evolution become a topic of discussion among scientists especially after the publication of the monumental book of Charles Darwin, The Origin of Species (1859), and The Descent of Man (1871). It is theorized that human being was developed from an "ape-like" ancestor that lived in tropical area, which had caused the loss of their fur pelt due to the warmer environment during their development. This idea was supported by Ernest with his History of Creation concept (1876). According to him, the human being was developed within a link from primates since the Tertiary time. This link was set up through primate's alalus: speak less/dump). Pithecanthropus alalus means the apeman who cannot speak.

Eugene Dubois an anatomist of Amsterdam University, believed that the Evolution Theory of Charles Darwin is especially important to trace human ancestor, so he decided to become a scientist to search the missing link. On October 29, 1887, Dubois with his family (wife and baby) leave the Netherland to Indonesia with steamship Princes Amalia (Figure 1) and arrived in Padang, Sumatra on December 11 of the same year.

Soon after, on Mei 1888, Dubois start to work at the Thousand Caves (Ngalau Seribu) Sibrambang, Lidah Ayer and Jimbe caves at Padang Hight land. The result was published under the title "Over de wenschelijkheid van een onderzoek naar de diluviale fanua van

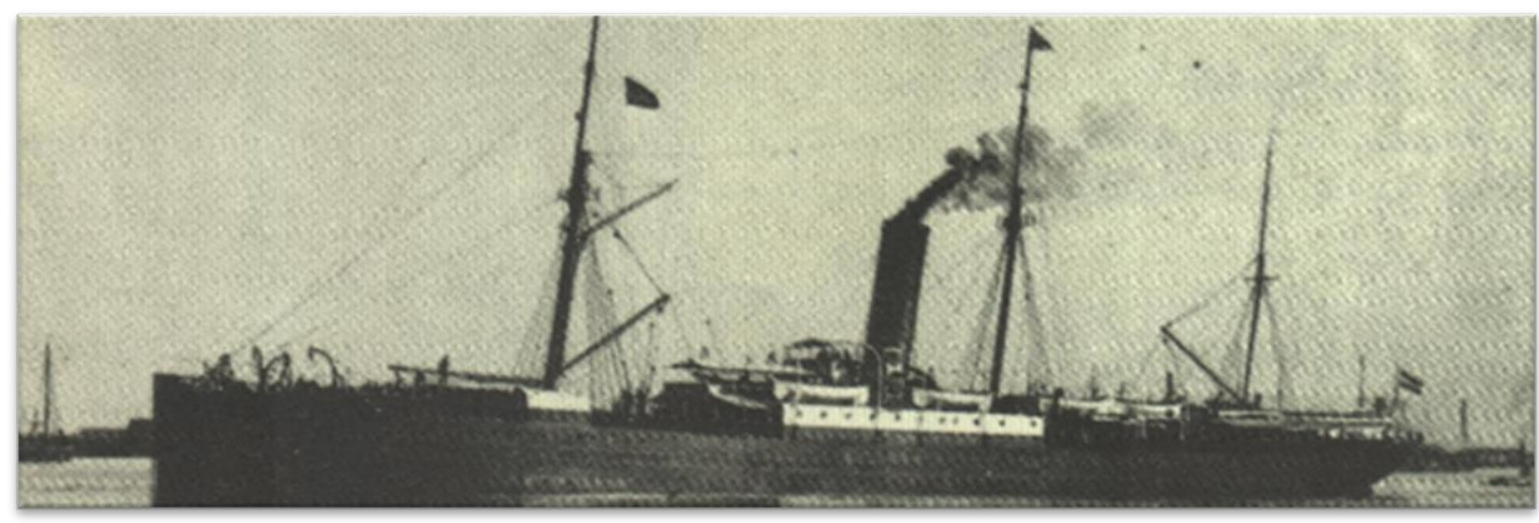

Figure 1. S.S. Amalia (photo).

evolution in the ability to walk upright with two-leg, speech dan increasing brain capacity. However, the theory suggested a missing link in human evolution from ape to human that Darwin called Pithecanthropus alalus (pithecus: ape, anthropus: human and
Nederlandsch Indie, In het bijzonde van Sumatera." On March 6, 1989, Dubois officially got an assignment from Dienst van het Mijnwezen, a precursor of the present Geological Survey Institute, to conduct paleontological 
research of the area (Aziz \& Purbo Hadiwidjojo, 1991).

In 1888 B.D. van Reitschoten who was looking for marble material at limestone cave near Wajak area, Gamping village, Campur Darat District, Tulung Agung Regency, East Java discovered a skull of human fossil (specimen Wadjak 1). This information reached Dubois that prompted his arrival to Java to conduct field activity. In 1890 he excavated Wajak and found another human skull (specimen Wadjak 2). Dubois also open field in the surrounding area of Madiun, Kediri, Surakarta, Rembang and Jepara, while setting his base camp at Tulung Agung. In Kedungbrubus Village, Caruban District, Madiun Regency, East Java Dubois found a hominid mandibular (specimen Kedungbrubus 1). In August 1891 Dubois visit Trinil because there is information that local people found a giant bone. Excavation was conducted in Trinil for 10 years period from 1890 - 1900. A right upper third molar was found in September 1891 and a skull cup was found one month after. Dubois attributed these to a species chimpanzee (Anthropopithecus) after he found the femur in Mei 1891

After a detailed study, Dubois believed that he had found a missing link in the human evolutionary line that he named Pithecanthropus erectus (Dubois, 1894). Pithecanthropus erectus means upright walking "ape-man." With the missing link finding, the skull cup specimen (Trinil 2) become the holotype and Trinil is the type locality. The discovery of "the missing link" shocked the world of science at that time and made Indonesia, especially the Geological Development Centre (Dienst van den Mijnbouw), were known throughout the world. Now Pithecanthropus erectus is well known as Homo erectus.

\section{Early 20th century}

During geological mapping activity, Ter Haar (1931) found a rich vertebrate fossil-bearing in teras deposit near Ngandong Village, Kradenan District, Blora Regency, Central Java Province. The following intensive excavation (1931-1933) found and collected eleven skulls and two tibiae of human fossils identified as Homo (Javanthropus) soloensis, an Asian type of Neanderthal man. In 1936, Andoyo an assistant of Dujfyes found an infant human fossil (Homo modjokertensis) estimated to be 610 years old child at Sumber Glagah village near Perning, Mojokerto. In the period of 1936-1940 Von Koenigswald collected a number of Homo erectus fossils from the Sangiran dome area. Research on human evolution by Indonesian experts began in the 1950s developing through the 1960s. Sartono from Institut Teknologi Bandung (ITB) who served as an expert at Geology Directorate (now Geological Research and Development Centre) and T. Jacob from Gajah Mada University collected new finding of Homo erectus from Sangiran, Sambungmacan, and Ngandong. At that time Geological Research and Development Centre obtained a specimen of Pithecanthropus VIII (P VIII) on September 13, 1969, that was found by Tukimin a local villager of Pucung. The fossil was dug out in situ from coarsegrained sandstone, a few meters below 


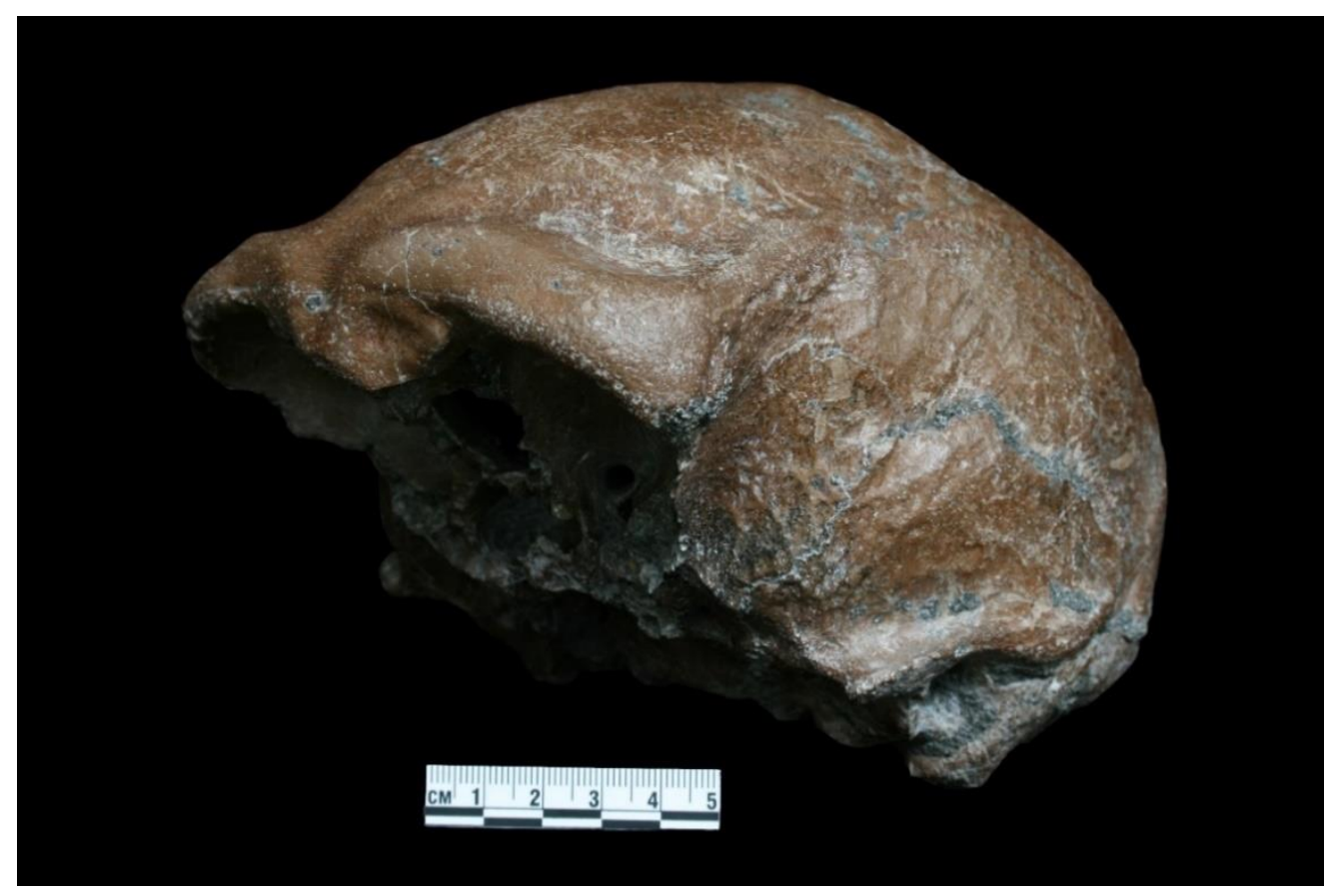

Figure 2. Homo erectus, Pithecanthropus VIII.

the middle Tuff of Bapang formation at Pucung village, the southern part of Sangiran dome area. This is the most complete skull of Asian Homo erectus with a substantial part of the face. In the maxilla, the teeth of P4 still attached and C, M1-M3 right were preserved. The specimen is important

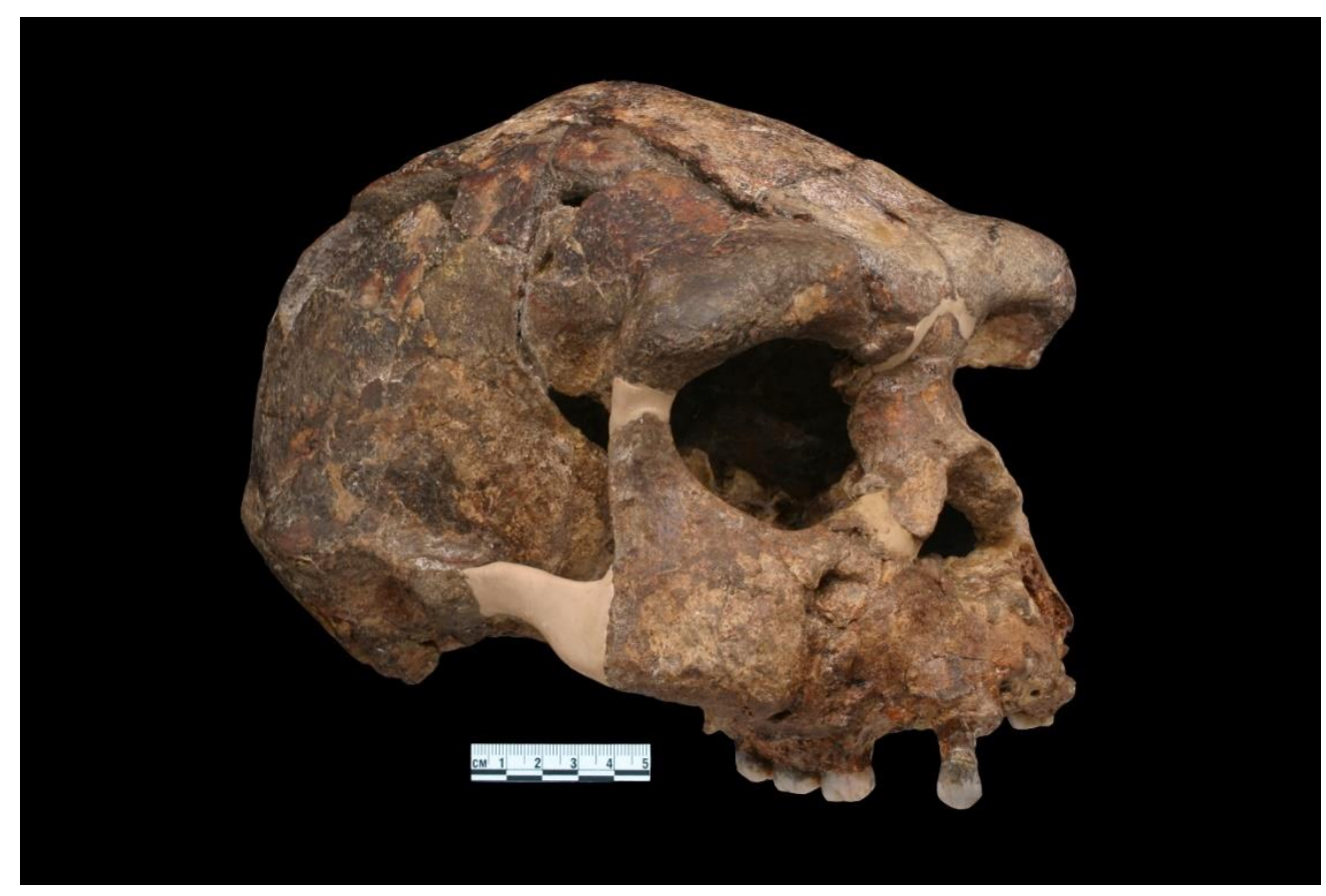

Figure 3. Homo erectus, Sambungmacan 4. 
to understand the "early phase" evolution of Indonesia's Homo erectus (Figure 2).

\section{Late 20th century}

In the period of 1980-2011, the Geological Research and Development Centre appointed Fachroel Aziz, a paleontologist, to oversee hominid fossil collections. Additional Homo erectus was obtained from the Sangiran dome area and Sambungmacan. In 2011, the Geological Research and Development Centre obtained a Homo erectus skull, specimen Sambungmacan 4 (Sm 4) from Darsono a villager of Cemeng village.

\begin{tabular}{|l|c|c|c|}
\hline & Early & Middle & Late \\
\hline & S 17 & Sm 4 & Ng 14 \\
\hline High and large vault & No & No & Yes \\
\hline Straight brow ridge & No & Int. & Yes \\
\hline Foramen magnum long & No & Yes & Yes \\
\hline Postcondyloid tuber & No & Yes & Yes \\
\hline Mandibular joint specialized & No & Int & Yes \\
\hline
\end{tabular}

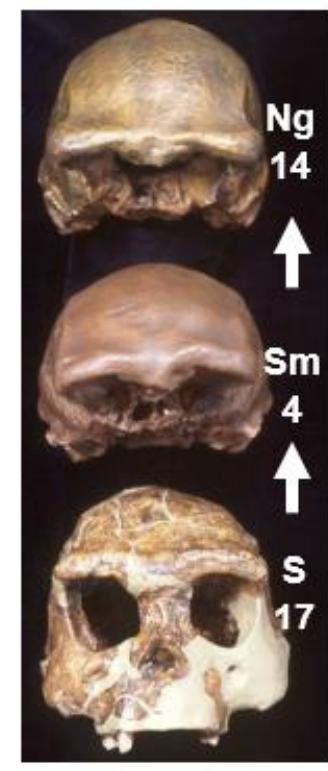

\begin{tabular}{|l|c|c|c|}
\hline & Early & Middle & Late \\
\hline & S 17 & Sm 4 & Ng 14 \\
\hline High and large vault & No & No & Yes \\
\hline Straight brow ridge & No & Int. & Yes \\
\hline Foramen magnum long & No & Yes & Yes \\
\hline Postcondyloid tuber & No & Yes & Yes \\
\hline Mandibular joint specialized & No & Int & Yes \\
\hline
\end{tabular}

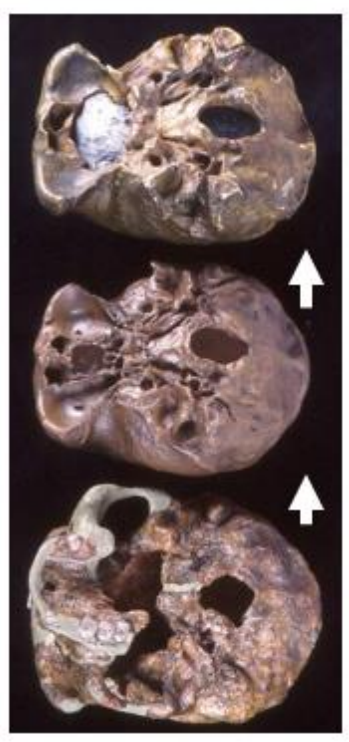

Figure 4. Development of derived features in Javanese Homo erectus from Early, via Middle, to Late forms. 
He found the skull while scooping up sand from the bottom of the Bengawan Solo River. The skull Sm 4 (Figure 3) is in unusually good bone surface condition. This is the best-preserved calvaria of Asian Homo erectus. The specimen is important to know the "middle phase" of Homo erectus evolution in Indonesia. A joint study between Geological Research and Development Centre, Bandung and National Museum of Science and Nature, Tokyo on Homo erectus saw a local evolution on the Indonesian specimens, concluded that Indonesian Homo erectus is not in a static evolution process (Figure 4).

The rich in natural resources and environmental conditions of Indonesia make it suitable for the evolution of early humans as suggested by the discovery of a number of Homo erectus skeleton fossils that are not found in most other countries.

\section{REFERENCES}

Aziz, F. and Baba, H. (eds.), 2013. Homo erectus in Indonesia. GRDC., Spec, Publ., 1-104.
Aziz, F and Purbo-Hadiwidjojo, M.M., 1991. In Quest of Fossil Hominid in Indonesia. Geological and Development Centre, Bandung. 2-8.

Darwin, C., 1859. The Origin of species by mean of Natural Selection. J.M. Dent \& Sons Ltd, London.

Darwin, C., 1981. The Decent of Man and Selection in the relation to Sex. John Tyler Bonner (ed). Princeton, New Jersey Pess.

Haeckel, E., 1876. The History of Creation, 28, London

Dubois, E., 1894. Pithecanthropus erectus, eine menschenaehnliche Uebergangfrom aus Java. Batavia, Landesdrukerei, 1-39

Oppenoorth, W.F.F., 1932. Homo (Javanthropus) soloensis, Een Plistocene Mensch van Java. Dienst van den Mijnbouw in NederlandshIndie, Wetenschappelijke Mededeelingen, 20:49- 75. 